\section{Effects of depleted uranium on immune parameters of zebrafish, Danio rerio, measured by flow cytometry}

\author{
B. Gagnaire, ${ }^{1}$ A. Bado-Nilles, ${ }^{2,3}$ \\ S. Betoulle, ${ }^{2}$ W. Sanchez ${ }^{3}$
}

'Institut de Radioprotection et de Sureté

Nucléaire (IRSN), Laboratoire

d'Ecotoxicologie des Radionucléides,

Saint-Paul-lez-Durance; ' 'Université

Reims Champagne-Ardenne, EA 4689

Unité Interactions Animal Environnement,

Reims; ${ }^{3}$ Institut National de

I'Environnement Industriel et des Risques (INERIS), Unité d'écotoxicologie in vitro et in vivo, Verneuil-en-Halatte, France

\section{Introduction}

Uranium is ubiquitous in natural waters at concentrations ranging from a few ng/L to low $\mu \mathrm{g} / \mathrm{L}$ depending on the composition of surrounding rocks and up to $1 \mathrm{mg} / \mathrm{L}$ at the vicinity of uraniferous sites. ${ }^{1}$ Depleted uranium (DU) is a byproduct of enriched uranium and is used in military, aviation, medical and research applications. Freshwater ecosystems may constitute the final receptor areas of DU to which they may be chronically exposed both to its chemical toxicity. ${ }^{2}$

Among all physiological processes possibly disturbed by pollutants, the immune system is likely to be one of the more sensitive physiological systems. ${ }^{3}$ Fish innate immune responses, which are the first line of immune system defence of these organisms may be suppressed by xenobiotics and seem to represent relevant immunotoxic endpoints. ${ }^{4}$ Keller et al. ${ }^{5}$ reported effects of cadmium, copper and zinc on immune parameters including total white blood cells, macrophage activity, and oxidative burst in several fish species. Mercury and selenite were also proved to be toxic to lysozyme activity and lymphocyte proliferation in blue gourami. ${ }^{6}$ Phagocytosis and oxidative burst were also reduced in the presence of cadmium or mercury in rainbow trout. ${ }^{7}$ However, data on effects of DU on fish immune system are scarce.

The objective of this work was to test the potential impacts of DU on zebrafish immune system using several endpoints measured by flow cytometry: cell population, cell mortality, reactive oxygen species (ROS) production, lysosome integrity and phagocytosis activity. Two separate experiments were conducted on zebrafish in order to assess DU effects in vivo on adults and ex vivo on leucocytes.

\section{Materials and Methods}

Freshly isolated leucocytes from naïve fish were exposed ex vivo during $17 \mathrm{~h}$ to $0,20,250$, $500 \mu \mathrm{g} \mathrm{DU} / \mathrm{L}$. In in vivo experiment, adults were exposed during 3 days to 20 and $250 \mu \mathrm{g} / \mathrm{L}$; a control with no DU was also added. Adult animals were sacrificed for sampling after 3 days in order to assess the activity of different immune parameters: cell sub-population, cell mortality (propidium iodide exclusion test), oxidative burst $\left[\mathrm{H}_{2}\right.$ DCFDA before and after stimulation by phorbol 12 -myristate 13 -acetate (PMA)], lysosomal membrane integrity (LMI) (acridine orange) and phagocytosis (fluorescent beads). At the end of the ex vivo contamination. The same biomarkers were measured on leucocytes exposed to DU, except for LMI. Results were expressed as percentage of positive cells for cell sub-population, mortality and phagocytosis, and as the mean fluorescence intensity for ROS production and LMI.

\section{Results and Discussion}

In the ex vivo experiment, ROS basal level was higher in cells exposed to DU for all tested concentrations (Table 1). ROS stimulated level showed no difference between control and DU concentrations (Table 1). ROS stimulation index was therefore lower in cells exposed to
Correspondence: Béatrice Gagnaire, IRS [N]/PRP-ENV/SERIS/LECO, Centre de Cadarache - Bât 186 - BP3, 13115 Saint-Paul-Lez-Durance, France.

E-mail: beatrice.gagnaire@irsn.fr

Key words: depleted uranium, zebrafish, flow cytometry.

Conference presentation: part of this paper was presented at the ECOBIM meeting, 2013 May, Montréal, Quebec, Canada.

This work is licensed under a Creative Commons Attribution NonCommercial 3.0 License (CC BYNC 3.0).

(C) Copyright B. Gagnaire et al., 2013

Licensee PAGEPress, Italy

Journal of Xenobiotics 2013; 3(s1):e3

doi:10.4081/xeno.2013.s1.e3

DU for all tested concentrations (Table 1). No other significant effect of DU was detected on other parameters tested.

In the in vivo experiment, ROS basal level was higher in fish exposed to DU for all tested concentrations (Table 2). ROS stimulated level was higher in fish exposed to $250 \mu \mathrm{g}$ DU/L (Table 2). ROS stimulation index was therefore lower in cells exposed to DU for all tested concentrations (Table 2). LMI was lower in fish exposed at $250 \mu \mathrm{g}$ DU/L (Table 2). No other significant effect of DU was detected on

Table 1. Effects of depleted uranium on leucocyte parameters during the ex vivo experiment. Values are means of 20 replicates, except for reactive oxygen species values for technical reasons (n comprised between 8 and 14); standard error is presented.

\begin{tabular}{lccc} 
[DU] (Hg/L) & ROS basal level (MFI) & ROS activated level (MFI) & ROS index \\
0 & $12.2 \pm 1.1^{\mathrm{a}}$ & $9.3 \pm 0.7$ & $0.90 \pm 0.1^{\mathrm{b}}$ \\
20 & $16.5 \pm 1.1^{\mathrm{ab}}$ & $7.6 \pm 1.1$ & $0.46 \pm 0.1^{\mathrm{a}}$ \\
\hline 250 & $19.2 \pm 2.3^{\mathrm{b}}$ & $7.5 \pm 1.1$ & $0.43 \pm 0.1^{\mathrm{a}}$ \\
500 & $20.4 \pm 3.2^{\mathrm{b}}$ & $7.8 \pm 1.0$ & $0.48 \pm 0.1^{\mathrm{a}}$ \\
\hline
\end{tabular}

DU, depleted uranium; ROS, reactive oxygen species; MFI, mean fluorescence intensity. a, significantly different from control at $\mathrm{P}<0.05 ; \mathrm{a}<\mathrm{b}$.

Table 2. Effects of depleted uranium on leucocyte parameters during the in vivo experiment. Values are means of 20 replicates, except for controls values $(n=18)$; standard error is presented.

\begin{tabular}{|c|c|c|c|c|}
\hline 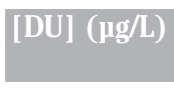 & $\begin{array}{l}\text { ROS basal level } \\
\text { (MIFI) }\end{array}$ & $\begin{array}{l}\text { ROS activated level } \\
\text { (MFI) }\end{array}$ & ROS index & $\begin{array}{l}\text { LMI } \\
\text { (MFI) }\end{array}$ \\
\hline 0 & $5.8 \pm 0.5^{\mathrm{a}}$ & $12.9 \pm 3.5^{\mathrm{a}}$ & $2.3 \pm 0.7^{\mathrm{b}}$ & $167.1 \pm 8.7^{\mathrm{b}}$ \\
\hline 20 & $12.2 \pm 1.1^{\mathrm{b}}$ & $11.5 \pm 1.3^{\mathrm{a}}$ & $1.0 \pm 0.1^{\mathrm{a}}$ & $149.8 \pm 7.3^{b}$ \\
\hline 250 & $14.9 \pm 1.4^{\mathrm{b}}$ & $17.3 \pm 1.2^{\mathrm{b}}$ & $1.2 \pm 0.1^{\mathrm{a}}$ & $130.3 \pm 5.5^{\mathrm{a}}$ \\
\hline
\end{tabular}

DU, depleted uranium; ROS, reactive oxygen species; MFI, mean fluorescence intensity; LMI, lysosomal membrane integrity. a, ${ }^{\mathrm{b}}$ significantly different from control at $\mathrm{P}<0.05 ; \mathrm{a}<\mathrm{b}$. 
other parameters tested.

LMI decreased in fish exposed to $250 \mu \mathrm{g}$ DU/L after 3 days. In earthworms, lysosomal stability decreased with increasing concentrations of U or DU in soils. ${ }^{8}$ In rat hepatocytes, DU induced lysosomal membrane rupture..$^{9,10}$ Therefore, our study confirmed that DU can affect the lysosomal membrane integrity in adult zebrafish.

DU increased ROS basal level with no modification on ROS PMA-stimulated level, leading to a reduction of ROS stimulation index in both in vivo and ex vivo experiments for all concentration tested. In rats, uranyl acetate and DU increased ROS basal level in kidney mitochondria. ${ }^{9} 10,11$ In a previous study, we showed an increase of ROS fold induction index in living whole kidneys removed from zebrafish exposed to $20 \mu \mathrm{g}$ DU/L during 28 days. ${ }^{12}$ It appears that DU induces the ROS basal production in zebrafish kidney leucocytes, showing a similarity to the mechanism of action of uranium known in mammals. This phenomenon could lead to an oxidative stress (inflammation) on the whole organism.

In conclusion, our study examined the effects of DU on immune parameters in zebrafish, Danio rerio for the first time. We showed that at environmentally-relevant concentrations of DU, an increase in ROS basal production, decrease of ROS stimulation by PMA and lysosomal membrane integrity in kidney leucocytes were produced. We conclude that DU could pose of risk to fish health in contaminated environments.

\section{References}

1. Bonin B, Blanc PL. L'uranium dans le milieu naturel, des origines jusqu'à la mine. In: Métivier H, editor. L'uranium de l'environnement à l'homme. Les Ulis: EDP Sciences; 2001. pp 7-41.

2. van Dam RA, Humphrey CL, Martin P. Mining in the Alligator Rivers Region, northern Australia: Assessing potential and actual effects on ecosystem and human health. Toxicology 2002;181182:505-15.

3. Wong S, Fournier M, Coderre D, Banska W, Krzystyniak K. Environmental immunotoxicology. In: Peakall D, ed. Animals biomarkers as pollution indicators. London: Chapman and Hall; 1992. pp 167-189.

4. Bols NC, Brubacher JL, Ganassin RC, Lee LE. Ecotoxicology and innate immunity in fish. Develop Comparat Immunol 2001;25: 853-73.

5. Keller JM, Meyer JN, Mattie M, Augspurger T, Rau M, Dong J, et al. Assessment of immunotoxicology in wild populations: review and recommendations. Rev Toxicol 1999;3:167-212.

6. Low KW, Sin YM. Effects of mercuric chloride and sodium selenite on some immune responses of blue gourami, Trichogaster trichopterus (Pallus). Sci Total Environ 1998;214:153-64.

7. Sanchez-Dardon J, Voccia I, Hontela A, Chilmonczyk S, Dunier M, et al. Immuno - modulation by heavy metals tested individually or in mixtures in rainbow trout (Oncorhynchus mykiss) exposed in vivo. Environ Toxicol Chem 1999;18:1492-7.

8. Giovanetti A, Fesenko S, Cozzella ML, Asencio LD, Sansone U. Bioaccumulation and biological effects in the earthworm Eisenia fetida exposed to natural and depleted uranium. J Environ Radioact 2010;101:509-16.

9. Pourahmad J, Ghashang M, Ettehadi HA, Ghalandari R. A search for cellular and molecular mechanisms involved in depleted uranium toxicity. Environ Toxicol 2006; 21:349-54.

10. Pourahmad J, Shaki F, Tanbakosazan F, Ghalandari R, Hossein Ali E, Dahaghin E. Protective effects of fungal beta-(1'3)-Dglucan against oxidative stress cytotoxicity induced by depleted uranium in isolated rat hepatocytes. Hum Exper Toxicol 2011; 30:173-81.

11. Shaki F, Hosseini MJ, Ghazi-Khansari M, Pourahmad J. Toxicity of depleted uranium on isolated rat kidney mitochondria. Biochim Biophys Acta 2012;1820:1940-50.

12. Gagnaire B, Cavalie I, Camilleri V, AdamGuillermin C. Effects of depleted uranium on oxidative stress, detoxification, and defence parameters of zebrafish Danio rerio. Arch Environ Contam Toxicol 2013; 64:140-50. 